\title{
Peat Swamp Forest; Management and Development of Indigenous Species to Support Economic Local People at Periphery Foret (Case Study in Central Borneo, Indonesia)
}

\author{
Lies Indrayanti ${ }^{*}$, Johanna Maria Rotinsulu', \\ Yanarita Yanarita ${ }^{1}$, Sosilawaty Sosilawaty ${ }^{1}$ \\ 1 University of Palangka Raya, Yos Sudarso Al/5, 73112, Palangka Raya, Indonesia \\ * Corresponding author's e-mail: indayantilies@for.upr.ac.id
}

\begin{abstract}
Jelutong Kapur and Sanaman are indigenous species at peat swamp forest. These plants have a great economic value. Besides the benefits from wood and sap, leaves can be used for medicinal purposes. The study aimed at obtaining the information related to the potential, distribution and increment diameter. This information was expected to be taken into consideration in the management and development of Jelutong. The study was conducted for 12 months in 12 observation plots, each plot measuring 100x100 m. The data were analyzed descriptively, while the growth patterns were shown graphically. The results showed that there were 100 Jelutong Kapur trees with a range $0-17$ trees/plot, an average 8 trees/hectare. It was higher than Jelutong Sanaman, where there were 65 trees with a range of $0-13$ trees/plot, an average 5 trees/hectare. However, jelutong Kapur had a diameter range $10.58-35.08 \mathrm{~cm}$, the average increment diameter is $0.69 \mathrm{~cm} /$ year, the highest in the diameter class $10-15.9 \mathrm{~cm}$ and 22-26.9 cm which is $0.68 \mathrm{~cm} /$ year. It is lower than Jelutong Sanaman the diameter of which ranges within $12.61-37.13 \mathrm{~cm}$, the average increment diameter is $0.77 \mathrm{~cm} /$ year, the highest increment in the class diameter of $10-15.9 \mathrm{~cm}$ is $0.85 \mathrm{~cm} /$ year. The highest and lowest number of trees is the same both in the diameter class $16-21.9 \mathrm{~cm}$ and $10-15.9 \mathrm{~cm}$. The base area of Jelutong Kapur was $0.41789 \mathrm{~m}^{2} / \mathrm{hectare}$, while in the case of Jelutong Sanaman it was $0.30422 \mathrm{~m}^{2} /$ hectare. In both of them the $16-21.9 \mathrm{~cm}$ diameter class, is dominant, i.e. constitutes $40 \%$. Both species may potentially support the economy for the local people, especially at forest periphery.
\end{abstract}

Keywords: Jelutong, indigenous species, increament, basal area, support economic

\section{INTRODUCTION}

Peat swamp forest has high biodiversity, both Forest Product(FP) and Non Timber Forest Product (NTFP). Some species are well-known, such as (in Indonesian or local name) Ramin (Gonystylus bancanus) dan Meranti (Shorea spp), Jelutung (Dyera spp), Kapur Naga (Dryobalanops spp), Kempas (Koompassia malaccensis), Keruing (Dipterocarpus appendioulatus), Banuas (Shorea obcsura), Kasundur (Sindora sp), Bangkirai (Shorea leavifolia Endart), Gaharu (Aqualaria spp) and gemur (Alseodaphne coriacea). (Simbolon, 2002). The biodiversity of species aside being natural resources that can be used for authorized capital of development state can also support the economy of local community, especially the local communities at forest periphery. Unfortunately, the results of the study by Sjarkowi (2005), found that most of the local population in Central Kalimantan depend on forest products. In some villages within peat swamp forest areas, $20-40 \%$ of the population was poor. On the other hand, most of the species above were limited, because the forest management policies in the past did not consider sustainability. Recently, the forest management had focused on the conservation function. The species were included in list of species conservation, meaning to restrict timber extraction, to prevent it from extinction. According to Simon (2010), he said that both the economic function and conservation function were nullified 
by each other. If the economic function more important, the conservation function will be ignored, and vice versa. In this case, it will become a dilemma, especially for the local communities who live at forest periphery, in which the needs of people and conservation function is equally important. How does the forest development can conform to both? Then, especially within local communities, the alternatives to timber extraction and used of NTFP as the fruit, leaves, bark and sap or latex from all of species in the forest must be found. Among these tree species in the peat swamp forest, there are an indigenous species i.e. Jelutong. This tree has a high economic value, because of wood and latex as well as leaves which can be used as medicine material (Wong, et al. 2011). The Jelutong latex provides material for the production of rubber, cover of cable, craft, cosmetics, etc. (William, 1963; Najiyati et al. 2005). The Jelutong wood has various uses, including guitar pars and biola component (Yahya et al., 2010), in addition to the material for meubel, plywood, canoe, pencils, etc. Therefore, to improve the usage of Jelutong and maintaining its existence, it is necessary to plan management and development. The management and development of Jelutong can be supported by investigating its potential, distribution and increment.

\section{MATERIAL AND METHOD}

The selected trees include two types of Jelutong i.e. Jelutong Kapur and Sanaman. The study was conducted at South Latitude between 20 20'457" - S 20 20'811" and East Longitude between 1140 02'007'-1140 01'888'. The study area was located in the Kalampangan peat swamp forest (Figure 1). The study used Global Positioning System for mapping observation plots and determining the tree position. Other tools include plastic meter for measuring the distance between plots or tree, metal meter for measuring the circumference of the tree, and paint for marking trees. The method used involved measuring the tree diameter at $1.3 \mathrm{~m}$ level from the ground. The measurements were for 12 months at four pathways out of seven existing ones.

In each pathway there are 3 plots, and the size of each plot is $100 \times 100 \mathrm{~m}$ (one hectare), so that the entire observation area is 12 hectares. The trees were then divided by four diameter class with $6 \mathrm{~cm}$ intervals, starting from $10 \mathrm{~cm}$. the diameter classes included 10-15, $9 \mathrm{~cm}, 16-21$, $9 \mathrm{~cm} .22-21,9 \mathrm{~cm}$ and over $27 \mathrm{~cm}$. Pathway, Plot and observation trees of Jelutong Kapur and Jeluoung Sanaman were shown in Figure 1.

The tree circumference data was then converted to diameter.The calculation of the basal area and increment of diameter was conducted using the respective formulas:

Konversi keliling menjadi diameter: $D=K / \pi$

where: $D$ - tree diameter $(\mathrm{cm})$,

$K$ - tree circumtance $(\mathrm{cm})$,

$\pi-$ constanta phi $=3.1415$.

Basal area: $G=1 /{ }_{4} \mu \cdot d^{2}$

where: $G-$ Tree basal area $(\mathrm{cm})$

$d$ - Tree diameter $(\mathrm{cm})$

Diameter increment: $R d=d n-d(n-1)$

where: $R d$ - tree diameter increment $(\mathrm{cm} / \mathrm{th})$

$d n$ - tree diameter year to $n(\mathrm{~cm})$

$d(n-1)$ - year diameter to $n(n-1)$

The results of the calculation were then processed using Snedecor \& Cochran (1956), which includes average values, standard deviation values and standard errors. The data and results of the calculations were analyzed descriptively, while the growth patterns were displayed graphically.

\section{RESULT AND DISCUSSION}

\section{Potency}

The numbers of Jelutong Kapur and Jelutong Sanaman at each pathway are shown inTable 1.

The number of Jelutong Kapur is greater than of Jelutong Sanaman at all pathways (Table.1). The total number of Jelutong Kapur is 100 trees which are distributed almost evenly on each pathway i.e. 23 to 27 trees. in the case of, Jelutong Sanaman, there are 65 trees at four pathways, with the distribution of about 13 to 22 trees. The information about the number of trees at each class diameter of Jelutong Kapur and Jelutong Sanaman is based on the result of measurement in each plot, shown in Table 2 below:

The Jelutong trees are relatively evenly distributed, as shown in Table 2, except at the fourth plot, where Jelutong Kapur are not found and at tenth plot where Jelutong Sanaman trees are missing in all class diameter. Jelutong Kapur have the distribution class diameter range of about $10-36 \mathrm{~cm}$. The lowest diameter found 


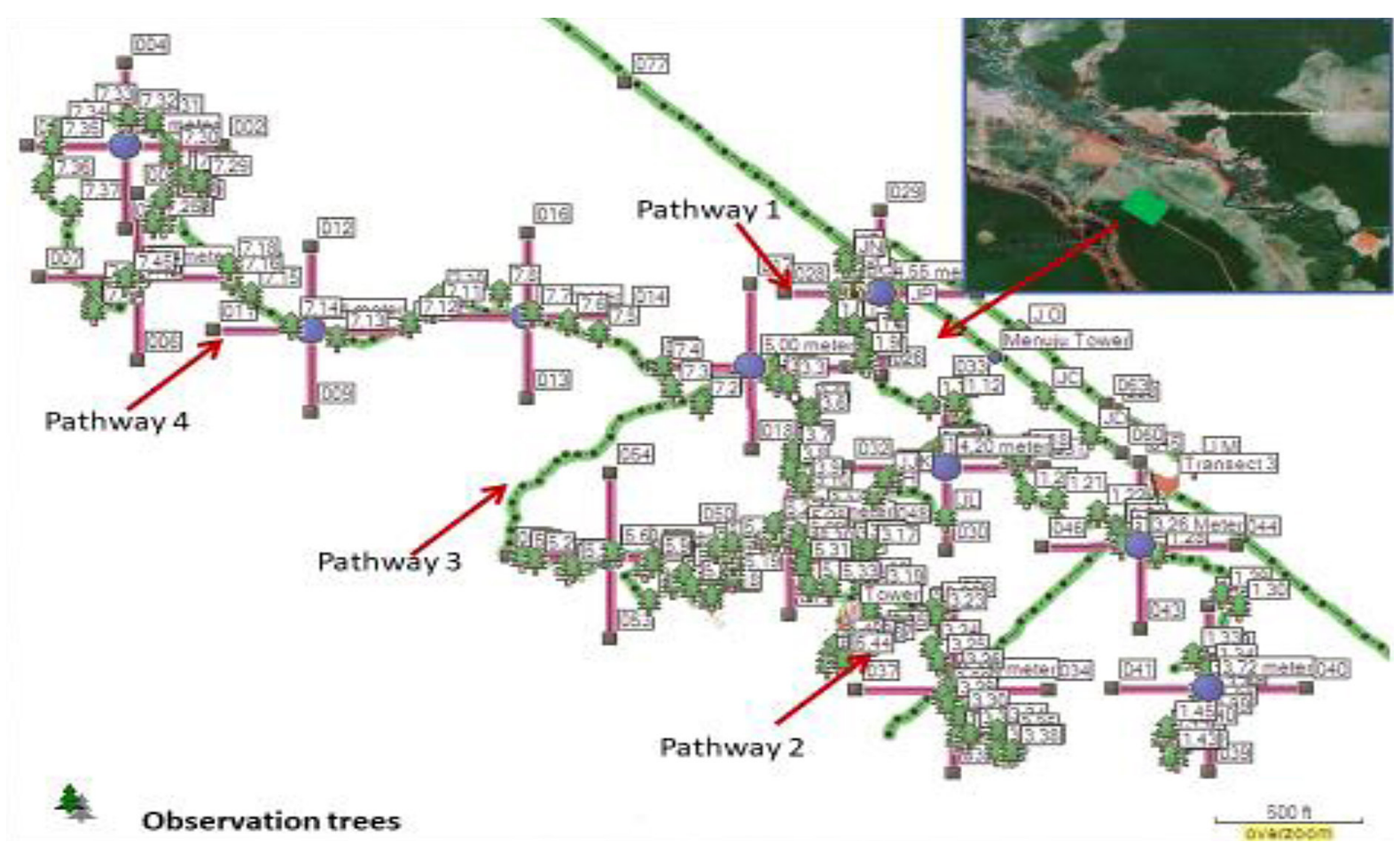

Figure 1. Pathway, Plot and Observation trees of Jelutong Kapur and Jelutong Sanaman

Table 1. The number of Jelutong Kapur and Jelutong Sanaman at four Pathways

\begin{tabular}{|c|c|c|c|c|}
\hline \multirow{2}{*}{ No. } & \multirow{2}{*}{ Pathway } & \multicolumn{2}{|c|}{ Numbers of Jelutung/Species } & \multirow{2}{*}{ Total Pathway (trees) } \\
\cline { 3 - 5 } & 1 & Jelutung kapur (trees) & Jelutung Sanaman (trees) & 45 \\
\hline 1 & 23 & 22 & 38 \\
\hline 2 & 3 & 27 & 13 & 44 \\
\hline 3 & 4 & 25 & 17 & 38 \\
\hline 4 & 100 & 65 & 165 \\
\hline
\end{tabular}

was $10.54 \mathrm{~cm}$, while the largest diameter was $35.08 \mathrm{~cm}$. The Jelutong Japur is dominated by the class diameter of $16-21,9 \mathrm{~cm}$. On the basis of the class diameter for Jelutong Kapur, it was found the diameter $16-21,9 \mathrm{~cm}$ or 37 tress $(37 \%)$ prevails, then class diameter $>27 \mathrm{~cm}(23 \%)$, the third place at class diameter $22-26 \mathrm{~cm}(21 \%)$ and the lowest was found at class diameter $10-15.9 \mathrm{~cm}$ (19\%), respectively. The Jelutong Sanaman trees (Table2) are distributesd relatively evenly, with the tree diameter classes ranging from $11-36 \mathrm{~cm}$. The lowest diameter found was $11.44 \mathrm{~cm}$, while the largest diameter was $36.75 \mathrm{~cm}$. Similarly to the Jelutong Kapur, based on the diameter class, most trees were found in the diameter class 16-21.9 $\mathrm{cm}$ (40\%), followed by the diameter class $22-26.9 \mathrm{~cm}(26.62 \%)$, the third place at the diameter class $>27 \mathrm{~cm}(20 \%)$, and the lowest at the diameter class 10-15. (21.538\%). Overall, the number of Jelutong Kapur was higher than of Jelutong Sanaman for all diameter classes. According to Daniel et al., (1987), the stand structure for the planted forest is determined by age of tree, while for natural forest - by tree diameter. Abdurrahman (2009) said that the stand structure is influenced by biotic, genetic and environment factors. Generally, the shape of stand structure natural forest is inverted $\mathrm{J}$. In that shape, the trees with small diameter prevail, then the diameter class increased, while the number of tree decreased (Abdurrahman, et al., 2009; Putra, 2015).

Both Jelutong Kapur and Jelutong Sanaman have the same pattern or have the same stand structure as shown in Figure 2

Daniel et al., (1987) said that the normal stand structure is an inverted bell; the highest frequency is around the middle value of the stand, then decreases at a larger diameter and is smaller than the 
Table 2. The number Jelutung Kapur Trees (Dyera lowii Hook) and Jelutung Sanaman trees in each plot base on diameter class

\begin{tabular}{|c|c|c|c|c|c|c|c|c|c|c|}
\hline \multirow{3}{*}{ Plot } & \multicolumn{5}{|c|}{ Jelutung Kapur } & \multicolumn{5}{|c|}{ Jelutung Sanaman } \\
\hline & \multicolumn{4}{|c|}{ Diameter class $(\mathrm{cm})$} & \multirow{2}{*}{ Total } & \multicolumn{4}{|c|}{ Diameter class $(\mathrm{cm})$} & \multirow{2}{*}{ Total } \\
\hline & $10.0-15.9$ & $16.0-21.9$ & $22.0-26.9$ & $>27.0$ & & $10.0-15.9$ & $16.0-21.9$ & $22.0-26.9$ & $>27.0$ & \\
\hline 1 & 0 & 6 & 4 & 4 & 14 & 0 & 1 & 1 & 0 & 2 \\
\hline 2 & 1 & 1 & 0 & 0 & 2 & 2 & 3 & 1 & 2 & 8 \\
\hline 3 & 3 & 5 & 3 & 5 & 16 & 0 & 6 & 4 & 2 & 12 \\
\hline 4 & 0 & 0 & 0 & 0 & 0 & 1 & 4 & 2 & 2 & 9 \\
\hline 5 & 5 & 8 & 2 & 2 & 17 & 1 & 5 & 3 & 4 & 13 \\
\hline 6 & 1 & 3 & 2 & 0 & 6 & 1 & 0 & 0 & 0 & 1 \\
\hline 7 & 2 & 4 & 1 & 0 & 7 & 2 & 0 & 1 & 0 & 3 \\
\hline 8 & 2 & 5 & 4 & 2 & 13 & 0 & 3 & 1 & 1 & 5 \\
\hline 9 & 1 & 3 & 3 & 2 & 9 & 0 & 1 & 0 & 0 & 1 \\
\hline 10 & 1 & 2 & 0 & 3 & 6 & 0 & 0 & 0 & 0 & 0 \\
\hline 11 & 1 & 0 & 1 & 1 & 3 & 1 & 0 & 0 & 1 & 2 \\
\hline 12 & 2 & 0 & 1 & 4 & 7 & 2 & 3 & 3 & 1 & 9 \\
\hline Total & 19 & 37 & 21 & 23 & 100 & 10 & 26 & 16 & 13 & 65 \\
\hline Average/ha & 1.58 & 3.08 & 1.75 & 1.92 & 8.33 & 0.75 & 2.17 & 1.33 & 1.08 & 5.42 \\
\hline
\end{tabular}

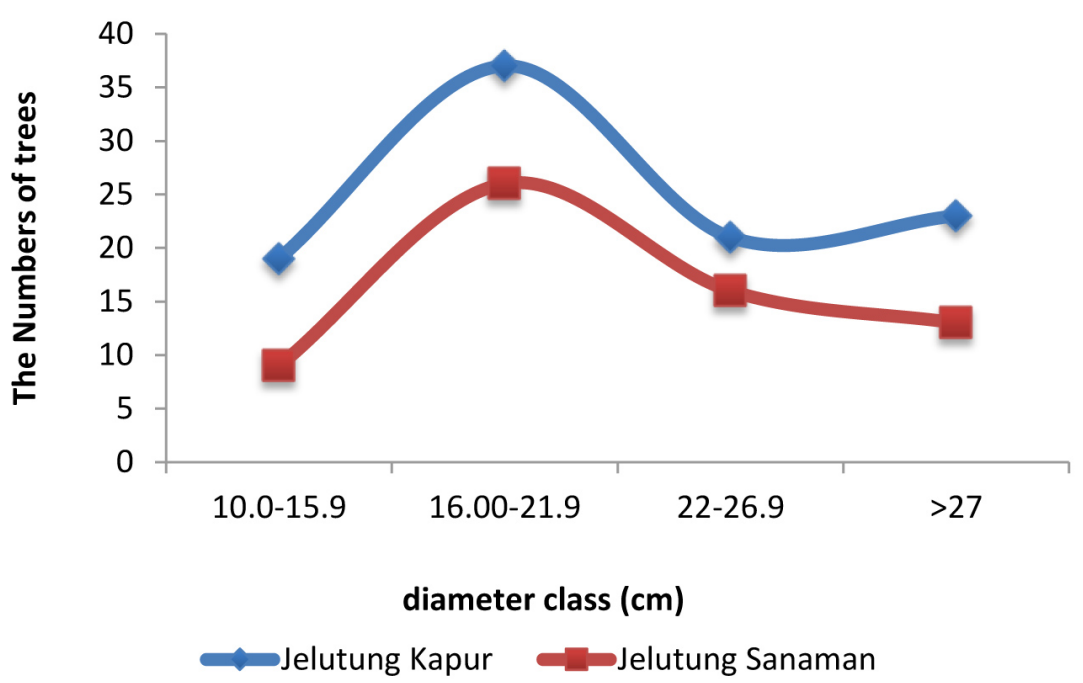

Figure 2. The number of Jelutong Kapur and Jelutong Sanaman based on diameter class.

average value. The stand structure of Sanaman jelutung Kapur and Jelutung according to what was stated by Daniel et al. (1987) is as follows: both types are domintated by the diameter class 16-21. $9 \mathrm{~cm}$, the average value is similar, i.e. $22.2 \mathrm{~cm}$, then the tree diameter s higher and the dominant diameter class is smaller. This is presumed because the peat swamp forest is a secondary forest that has become a conservation area. There are no activities to clear the forest floor so that low-level plants are difficult to develop, because of the lack of light. The differences in the number of trees in each diameter class, is simultaneously influenced by some factors, i.e light and nutriens. Simbolon (2002) research conducted at the same location, said that the stand density reached $70 \%$, so it did not provide enough space and light for saplings or for small diameter trees; consequently, small diameter trees tend to have a large mortality rate. The result of research on soil properties carried out in the same location by Indrayanti (2015) found that the level of soil acidity in this area is very high, even extreme, i.e. in the range of $\mathrm{pH} 2.0-2.3$. Such low $\mathrm{pH}$ value will inhibit the absorption of nutrients by the roots, and then inhibit growth. The fact that the number of trees for low-class diameters is small is a genetic factor. Jelutong has the shape of a seed pod. Commonly, the seed pod will break mature, so that the seeds inside will fall, before reaching 
the ground due to the wind. This situation causes fewer plants around the mature tree to be even less even. The range of Jelutong Kapur at each plot reaches $0-17$ trees or average 8,33 tree/ ha, while the range Jelutong Sanaman corresponds to $1-13$ tree/plot, or average 5.42 tree/ha. The research result was greater than in William (1963) at riau and Bangka Belitung, which was 1-4 tree/ha.

\section{Basal Area}

The basal area of the tree is the cross-sectional; therefore, for the cross-sectional area of all stands in an area describes a stand that covers an area. This field is measured at an altitude of 1.30 meters above ground level. The basal area of the Jelutong Kapur and Jelutong Sanaman in each observation plot can be seen in the following Tables 3 and 4:

In both tables above, it can be seen that the sequence of the basal area of the two types of Jelutong is similar. The data are sorted from the largest to the smallest according to the number of trees. However, there is a striking difference between the Jelutong diameter class of 10-15.9 cm and the three classes of greater diameter. For example, the basal area of Jelutong Kapur diameter class $10-15.9 \mathrm{~cm}(5.95 \%)$ is $19 \%$, while the basal area of the class diameter $16-21.9 \mathrm{~cm}(39.4 \%)$ is $37 \%$. Overall, the average basal area of Jelutong Kapur is $0.42 \mathrm{~m}^{2} /$ ha, with the highest basal area found in plot 6 , followed by plot 3 and plot 1 . This is very different from the highest number of trees found in plot 5 followed by plots 3 and 1 . The average basal area of Jelutong Sanaman is $0.34 \mathrm{~m}^{2}$ / ha, with the highest basal area found in plot 8 , then followed by plot 5 and plot 7. Similarly to Jelutong Kapur, the Jelutong Sanaman is also different for the highest number of trees found in plot 5 then followed by plot 3 and plot 4 . This means that the number of large trees does not determine the size of the basal area. This is caused by the diameter class, even though the number of large trees but small diameter, it will produce a small base area too, and vice versa.

\section{Diameter Increment}

The results of continuous diameter measurements for 12 months were obtained by calculating the diameter increment of two types of Jelutong. The description of the average value of Jelutong Kapur and Jelutong Sanaman can be seen in Table 5.

The average value of Jelutong diameter increments as in Table 5 for Jelutung Kapur is $0.69 \mathrm{~cm} /$ year, which is lower than the average value of Jelutong Sanaman, amounting to $0.77 \mathrm{~cm} /$ year. These results are lower than the growth rate of Jelutong plant of 4-5 year old which was conducted by Sofiyuddin et al. (2012) in Tanjung Jabung, Jambi province. The results of the study found the Jelutong growth rate which varies according to the cropping pattern. The Jelutong growth rate for the monoculture planting pattern reached $1.9 \mathrm{~cm} / \mathrm{year}$, and $1.6 \mathrm{~cm} /$ year in the mixed palm and Jelutong cropping pattern. The growth rate in a mixture oil

Table 3. Basal Area of Jelutong Kapur at each observation plot

\begin{tabular}{|c|c|c|c|c|c|}
\hline \multirow{3}{*}{ Plot } & \multicolumn{5}{|c|}{ Basal Area (M2) } \\
\hline & \multicolumn{4}{|c|}{ Diameter Class $(\mathrm{Cm})$} & \multirow{2}{*}{ Total } \\
\hline & $10.0-15.9$ & $16.0-21.9$ & $22.0-26.9$ & $>27.0$ & \\
\hline 1 & 0.0000 & 0.2472 & 0.1907 & 0.2594 & 0.6974 \\
\hline 2 & 0.0190 & 0.0211 & 0.0000 & 0.0000 & 0.0401 \\
\hline 3 & 0.0534 & 0.1480 & 0.1378 & 0.4036 & 0.7428 \\
\hline 4 & 0.0000 & 0.0000 & 0.0000 & 0.0000 & 0.0000 \\
\hline 5 & 0.0816 & 0.2510 & 0.1094 & 0.1159 & 0.5579 \\
\hline 6 & 0.0099 & 0.9510 & 0.0947 & 0.0000 & 1.0556 \\
\hline 7 & 0.0290 & 0.1061 & 0.0526 & 0.0000 & 0.1877 \\
\hline 8 & 0.0237 & 0.1412 & 0.1801 & 0.1668 & 0.5118 \\
\hline 9 & 0.0187 & 0.0760 & 0.1225 & 0.1338 & 0.3510 \\
\hline 10 & 0.0108 & 0.0611 & 0.0000 & 0.2218 & 0.2938 \\
\hline 11 & 0.0144 & 0.0000 & 0.0558 & 0.0905 & 0.1607 \\
\hline 12 & 0.0377 & 0.0000 & 0.0506 & 0.3276 & 0.4159 \\
\hline Total & 0.2983 & 2.0027 & 0.9942 & 1.7194 & 5.0147 \\
\hline Average/Plot/Ha & 0.0249 & 0.1669 & 0.0829 & 0.1433 & 0.4179 \\
\hline Procentation (\%) & 5.9486 & 39.9378 & 19.8261 & 34.2875 & \\
\hline
\end{tabular}


Table 4. Basal Area of Jelutong Sanaman at each observation plot

\begin{tabular}{|c|c|c|c|c|c|}
\hline \multirow{2}{*}{ Plot } & \multicolumn{4}{|c|}{ Basal Area (M2) } & \multirow{2}{*}{ Total } \\
\cline { 2 - 5 } & $10.0-15.9$ & $16.0-21.9$ & $22.0-26.9$ & $>27.0$ & 0.0801 \\
\hline & 0.0000 & 0.0284 & 0.0517 & 0.0000 & 0.3245 \\
\hline 2 & 0.0334 & 0.0718 & 0.0406 & 0.1787 & 0.5028 \\
\hline 3 & 0.0000 & 0.1807 & 0.1715 & 0.1506 & 0.4164 \\
\hline 4 & 0.0198 & 0.1219 & 0.0959 & 0.1788 & 0.6045 \\
\hline 5 & 0.0191 & 0.1662 & 0.1277 & 0.2914 & 0.0163 \\
\hline 6 & 0.0163 & 0.0000 & 0.0000 & 0.0000 & 0.5560 \\
\hline 7 & 0.0297 & 0.0000 & 0.5262 & 0.0000 & 0.9461 \\
\hline 9 & 0.0000 & 0.8047 & 0.0392 & 0.1022 & 0.0321 \\
\hline 10 & 0.0000 & 0.0321 & 0.0000 & 0.0000 & 0.1207 \\
\hline 11 & 0.0125 & 0.0000 & 0.0000 & 0.1082 & 0.0000 \\
\hline 12 & 0.0000 & 0.0000 & 0.0000 & 0.0000 & 0.4676 \\
\hline Total & 0.0323 & 0.0662 & 0.1345 & 0.2346 & 4.0670 \\
\hline Average/plot/ha & 0.1631 & 1.4719 & 1.1874 & 1.2446 & 0.3389 \\
\hline Procentase (\%) & 0.0136 & 0.1227 & 0.0989 & 0.1037 & \\
\hline
\end{tabular}

Table 5. Average Diameter Increment, Standard Deviation, Variance and Standard Error of Jelutong Kapur and Jelutong Sanaman

\begin{tabular}{|l|c|c|c|c|}
\hline \multicolumn{1}{|c|}{ Species } & Average & Deviasi Standard & Variance & Error Standard \\
\hline Jelutung Kapur & 0.687 & 0.339 & 0.115 & 0.034 \\
\hline Jelutung Sanaman & 0.770 & 0.241 & 0.058 & 0.032 \\
\hline
\end{tabular}

palm and Jelutong equaled $1.0 \mathrm{~cm} /$ year. It is understandable that differences occur in Jelutong which grows naturally because of maintenance and fertilization. However, the results of this study are higher than the results of a study by Simbolon conducted in the same location study in 2002 on Jelutong Kapur, which was $0.112 \mathrm{~cm} /$ year. The growth rate of both types of Jelutong according to the diameter class can be seen Figure 3
The Jelutong Sanaman growth rates have a higher level than in the case of Jelutong Kapur in all diameter classes. Both have the same pattern, namely the highest growth rate in the diameter class $22-26.9 \mathrm{~cm}$, which is $0.85 \mathrm{~cm} /$ year, the results of this study are lower than in the study by Indrayanti et al. (2017) on natural Jelutung which is equal to $1.08 \mathrm{~cm} /$ year, for diameter classes $18.5-26.5 \mathrm{~cm}$. Although the

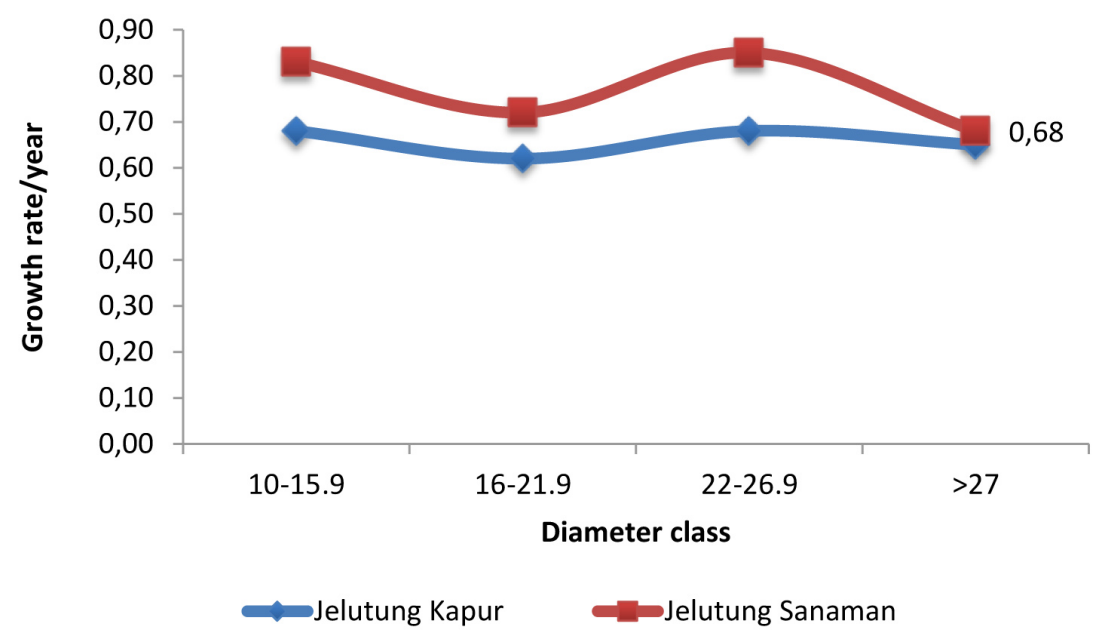

Figure 3. Growth diameter of Jelutong Kapur and Jelutong Sanaman based on diameter class 
growth rate of Jelutong Sanaman is higher than of Jelutong Kapur, it turns out the results latex yield are opposite. Jelutong Sanaman has a lower latex yield compared to Jelutong Kapur (Indrayanti, 2015).

Generally, the larger the tree or the increasing age of the tree, the lower the growth rate (Krisnawati et al. 2011). The decrease in the growth rate of Jelutung trees in the larger tree is diameter class, thought to be due to the larger size which also requires more photosynthetic energy to support metabolic processes such as respiration, translocation, and absorption of mineral water and nutrients, so there is not much energy remaining for growth (Pamoengkas and Prayogi, 2011).

\section{Prospect of Jelutong to Economic Support of Local Communities}

As explained before, Jelutong have a high economic value because they provide latex. According to Indrayanti (2018), the latex yield of Jelutong Kapur is about $150 \mathrm{ml} /$ tree/tap. Furthermore, she said that the highest latex yield occurs at diameter class $16-22 \mathrm{~cm}$. The above-mentioned research indicates that the same diameter class corresponds to the highest number of Jelutung and growth rate. Therefore, the Jelutong is a prospective support as additional income for local communities. As illustrated, the latex can be tapped from 40 trees in one day (William, 1963). According Setiawan and Andoko (2008) the best tapping frequency on one tree is four times a week. Considering that the latex price is IDR $10000 / \mathrm{kg}$, and each household has 300 Jelutong trees, it adds up to IDR 21, 6 million/year. The latex yield can support the economy of local communities, and maintain the forest condition without timber extraction.

\section{CONCLUSION}

Both types of Jelutong have the potential for development at degraded area in peatland, because they constitute indigenous species. Beside reclamation, both types of Jelutong provide benefits of latex yield that can increase the income of local communities.

\section{Acknowledgements}

Special thanks to CIMTROP, that gave me a chance to conduct research at Kalampangan Peat swamp forest.

\section{REFERENCES}

1. Abdurachman, Saridan, A and Lanniari, I. 2009. Potency, Diameter Increament of aqualaria malaccensis LMAK at Natural Forest Production Labanan, Berau District, West Borneo Province. Journal of Forest Research and Natural Concervation, VI (1), 1-11.

2. Daniel, T.W., Helms JS., Baker F.1987. Principal of Silviculture .Djoko Marsono, Translater, Oemi H.S editor. Yogyakarta.Gadjah Mada University Press.

3. Hariadi, K. 2009. Forest Area and Policy of Forest Management in Central Borneo. Paper, Presented at Seminar of PERSAKI.

4. Indrayanti.L.,S.N Marsoem.,T.A Prayitno.,H. Supriyo.,B.Radjagukguk. 2015. The Thickness Distribution of Peat Land and the Properties of Peat Land at Peat Swamp Forest Kalampangan, Central Kalimantan. Jurnal Wana Tropika, 5(1), 52-67

5. Indrayanti, L.2015. Growth Rata, Wood Properties and Latex Yield of Jelutung Kapur and Jelutung Sanaman at Three Class Peat Thickneses and Three Diameter Class Ph.D..Thesis.Repository. ugm.ac.id. Yogyakarta.

6. Indrayanti.L. Sosilawaty., Rotinsulu, J.M. 2017. Growth Rate of Swamp Jelutung (Dyera lowii Hook.F) Tapped and Untapped. Journal AGRIENVI, 11(2), 40-52

7. Indrayanti.L. Sn Marsoen., T.A Prayitno., Misrita., Nursiah. 2018. The Yield and Content of LatexTwo Types of Jelutong. Paper. Presented at National Seminar Technology of Forest Product, University of Mulawarman, South Borneo.

8. Krisnawati, H., Kallio, M dan Kanninen, M. 2011 Aleurites moluccana (L.) Willd. Ecology, Silviculture and Productivities.CIFOR, Bogor, Indonesia.

9. Najiyati, S., Lili, M dan Nyoman, I.S. 2005. Guiden of Management Peatland for Sustaibale Agriculture. Project Climate Change, Forest and Peatlands In Indonesia. Wetlands International- Indonesia Programmed and Wildlife Habitat Canada. Bogor.Indonesia.

10. Pamoengkas, P dan Randana, F. 2013. Response of Growth Rate Red Meranti against Width of Path Planting and Solar Inrtensity andSilvicultre System. Journal Silviculture Tropica, 4(1), April, $51-56$ 
11. Pamoengkas, P dan Junior, P. 2011. Growth Rate of Red Meranti (Shorea leprosula Miq) in Silviculture System Selection Planting Path (Case Study at IUPHHK-HA area, PT. Sari Bumi Kusuma Central Borneo). Jurnal Silviculture Tropica. 2(01), 9-13.

12. Putra, A.T. 2015. Analysis Stand Potency Result of Forest Inventory at KPHP Model West Berau. Jurnal Agrifor.XIV (2), Oktober, 147-160

13. Simbolon, H.2002. Initial Proses Restoring Peatland Forest Kalampangan Central Borneo Pasca Forest Fire on Desember 1997 and September 2002. Research Center for Biology- Indonesian Institute Sciences. Bogor Indonesia.

14. Simon, H. 2010. Planning for Forest Resources Development Timber Management. Pustaka Pelajar.Yogyakarta.
15. Sofiyuddin, M., Janudianto and Perdana, A. 2012. Potency for Development and Marketing of Jelutung in Tanjung Jabung Barat. Brief no 23. Bogor. Indonesia. World Agroforestry Center-ICRAF, SEA Regional Owffice.

16. Williams, L. 1963. Laticiferous Plants of Economic Importance IV Jelutong (Dyera spp). Economi Botany. 17(2), 110-126.

17. Wong, S.K., Lim, Y.Y., Noor R.A dan Fariza, J.N. 2011. Assesment of antiprolifea and anti plasmodial activities of five selected Apocynaceae species. BMC Complementary an Alternative Medicine. 11, 3.

18. Yahya, S., Hamdan, S., Jusoh.I dan Hasan, M. 2010. Acoustic properties of selected tropical wood species. J. Nondestruct Eval 29, 38-42. 